\title{
Deoxyribonucleic Acid Reassociation Between Strains of Bacillus firmus, Bacillus lentus, and Intermediate Strains
}

\author{
TATSUJI SEKI, MASASHI MINODA, JUN-ICHI YAGI, AND YASUJI OSHIMA* \\ Department of Fermentation Technology, Osaka University, 2-1 Yamadaoka, Suita-shi, Osaka 565, Japan
}

\begin{abstract}
Deoxyribonucleic acid homologies were examined in 23 strains labeled Bacillus firmus, Bacillus lentus, or intermediate between these two species. With one exception (strain NRS 1560), the 11 strains assigned to $B$. firmus showed high homologies with the deoxyribonucleic acid of the type strain of $B$. firmus (ATCC 14575). However, the strains labeled $B$. lentus (five strains) or intermediate (seven strains) showed low homologies (approximately 5\%) with the standard strains of $B$. firmus and with each other, except for one intermediate strain (NRS 1369), which showed high homology ( $98 \%$ ) with one of the standard strains of $B$. firmus, and strains NRS 883 and NRS 1262 (both labeled $B$. lentus), which showed high homology (50\%) with each other.
\end{abstract}

Bacillus firmus and Bacillus lentus have long been confused. Both species were originally classified as $B$. firmus (2), but in 1935 Gibson (1) established a new species, $B$. lentus, based on the distinctive characteristics of urease production and failure to decompose casein and gelatin. In 1977, Gordon et al. (3) investigated 46 strains of the B. firmus-B. lentus series (20 strains of $B$. firmus, 8 strains of $B$. lentus, and 18 intermediate strains) and suggested that all 46 strains should be assigned to the same species, $B$. firmus (the older species name). However, we have observed significant heterogeneity in deoxyribonucleic acid (DNA) base sequences by performing DNA-DNA hybridization between the type strains of $B$. firmus (ATCC 14575) and $B$. lentus (ATCC 10840) (7). To clarify their species identities, we investigated the DNA homologies of 23 of the 46 strains subjected to conventional taxonomic study by Gordon et al. (3).

The 23 strains tested in this study are listed in Table 1. We could not test the remaining 23 strains because of their poor growth in liquid medium or difficulties in DNA preparation. A thymine-requiring mutant of an intermediate strain, NRS 749, was isolated by trimethoprim enrichment (8). Bacillus subtilis 168 was used as a reference strain.

Nutrient broth $(8 \mathrm{~g} /$ liter; Difco Laboratories, Detroit, Mich.) containing $5 \mathrm{~g}$ of polypeptone (Wako Pure Chemical Industries, Osaka, Japan) per liter or doubly fortified nutrient broth (16 $\mathrm{g} /$ liter) containing $6.7 \mathrm{~g}$ of yeast-nitrogen base without amino acids (Difco) per liter was used for general cultivation of cells. All media were adjusted to $\mathrm{pH}$ 7.0. Cells cultivated in a nutrient medium were harvested at the late logarithmic phase, and the DNA was extracted by the meth- od of Marmur (4). When cells were resistant to treatment with lysozyme and sodium dodecyl sulfate, 2,000 U of penicillin G (Meiji Seika Co., Ltd., Tokyo, Japan) per ml was added to the culture in the mid-logarithmic phase, and cultivation was continued for $2 \mathrm{~h}$. The cells were harvested, washed with $0.15 \mathrm{M} \mathrm{NaCl}-0.1 \mathrm{M}$ ethylenediaminetetraacetic acid ( $\mathrm{pH} \mathrm{8.0)}$, and suspended in the same solution containing $0.25 \mathrm{~g}$ of sucrose per $\mathrm{ml}$. The resulting suspension was frozen several times in an acetone-dry ice bath and thawed, and then the DNA was extracted.

Tritium-labeled DNAs were prepared by either in vivo labeling or in vitro labeling. The in vivo labeling was performed by cultivating cells in Spizizen minimal medium (9) supplemented with $5 \mathrm{~g}$ of Casamino Acids (Difco) per liter, 6.7 $\mathrm{g}$ of yeast nitrogen base per liter, $1 \mathrm{mg}$ of biotin per liter, $10 \mathrm{mg}$ of thiamin per liter, $2 \mathrm{mg}$ of thymine per liter, and $1.25 \mathrm{mCi}$ of [methyl${ }^{3}$ H]thymine (The Radiochemical Centre, Amersham, England) per liter, as described previously (8). For in vitro labeling, [methyl${ }^{3} \mathrm{H}$ ]deoxythymidine triphosphate (The Radiochemical Centre) was incorporated into DNA instead of $\left[{ }^{32} \mathrm{P}\right]$ deoxycytosine triphosphate by nick translation (6), using DNA polymerase I (Boehringer Mannheim GmbH, Mannheim, West Germany) and deoxyribonuclease I (Boehringer).

DNA-DNA hybridization was conducted on nitrocellulose membrane filters, as described previously (8). A $1-\mathrm{ml}$ solution containing approximately $0.5 \mu \mathrm{g}$ of denatured $\left[{ }^{3} \mathrm{H}\right] \mathrm{DNAs}$ (input DNA) prepared from seven reference strains (B. firmus ATCC $14575^{\mathrm{T}}$ [type strain] and NRS $853, B$. lentus NRS 783 and NRS 883, and intermediate strains NRS 1369, NRS 749, and NRS 1575) was hybridized with $25 \mu \mathrm{g}$ of dena- 
TABLE 1. DNA homologies between $B$. firmus, B. lentus, and intermediate strains ${ }^{a}$

\begin{tabular}{|c|c|c|c|c|c|c|c|}
\hline \multirow{3}{*}{ Strain ${ }^{b}$} & \multicolumn{7}{|c|}{ Input DNA homology (\%) to: } \\
\hline & \multicolumn{2}{|c|}{ B. firmus } & \multicolumn{3}{|c|}{ Intermediate strains } & \multicolumn{2}{|c|}{ B. lentus } \\
\hline & $\begin{array}{l}\text { ATCC } \\
14575^{\text {Tc }}\end{array}$ & $\begin{array}{l}\text { NRS } \\
853^{d}\end{array}$ & $\begin{array}{l}\text { NRS } \\
1369^{d}\end{array}$ & $\begin{array}{l}\text { NRS } \\
749^{c}\end{array}$ & $\begin{array}{l}\text { NRS } \\
1575^{d}\end{array}$ & $\begin{array}{l}\text { NRS } \\
7^{\prime} 3^{d}\end{array}$ & $\begin{array}{l}\text { NRS } \\
\mathbf{8 8 3}^{d} \\
\end{array}$ \\
\hline \multicolumn{8}{|l|}{ B. firmus } \\
\hline ATCC $14575^{\mathrm{T}}$ & 100 & 100 & 104 & 4 & 8 & $\mathrm{NT}^{e}$ & 4 \\
\hline NRS 613 & 100 & 91 & 48 & 10 & 4 & 6 & 3 \\
\hline NRS 853 & 103 & 100 & 64 & 7 & 4 & 6 & 3 \\
\hline NRS 854 & 106 & 93 & 49 & 6 & 4 & 3 & 3 \\
\hline NRS 855 & NT & 73 & 69 & 5 & 5 & 6 & 4 \\
\hline NRS 858 & 56 & 106 & 84 & 4 & 6 & 5 & 3 \\
\hline NRS 860 & 98 & 84 & 68 & 7 & 4 & 4 & 3 \\
\hline NRS 861 & 79 & 96 & 80 & 9 & 7 & 5 & 2 \\
\hline NRS 1070 & 107 & 65 & 52 & 9 & 2 & 2 & 2 \\
\hline NRS 1131 & 90 & 66 & 76 & 6 & 4 & 2 & 2 \\
\hline NRS 1560 & 5 & NT & NT & 9 & NT & NT & NT \\
\hline \multicolumn{8}{|c|}{ Intermediate strains } \\
\hline NRS 1369 & NT & 98 & 100 & 4 & 2 & 4 & 4 \\
\hline NRS 1370 & 4 & NT & NT & 5 & NT & NT & NT \\
\hline NRS 1148 & 3 & NT & NT & 4 & NT & NT & NT \\
\hline NRS 749 & 4 & 7 & 1 & 100 & 8 & 3 & 3 \\
\hline NRS 1151 & 1 & 2 & 1 & 1 & 2 & 1 & 2 \\
\hline NRS 1575 & 4 & 4 & 3 & 16 & 100 & 2 & 4 \\
\hline NRS 1570 & 4 & NT & NT & 5 & NT & NT & NT \\
\hline \multicolumn{8}{|l|}{ B. lentus } \\
\hline NRS 769 & 4 & NT & NT & 4 & NT & NT & NT \\
\hline NRS 783 & 3 & 9 & 3 & 6 & 4 & 100 & 2 \\
\hline NRS 883 & 4 & 4 & 3 & 6 & 4 & 3 & 100 \\
\hline NRS 1262 & 5 & 1 & 1 & 5 & 2 & 3 & 50 \\
\hline NRS 1571 & 4 & NT & NT & 4 & NT & NT & NT \\
\hline B. subtilis 168 & 4 & 3 & 1 & 5 & 2 & 2 & 2 \\
\hline
\end{tabular}

${ }^{a}$ Homologies are expressed as percentages of input DNA bound to a certain disk DNA relative to the binding of the homologous combination.

$b$ The strains are arranged according to the taxonomic classification of Gordon et al. (3). NRS, collection of the late N. R. Smith, U. S. Department of Agriculture, obtained via R. E. Gordon, Rutgers University; ATCC, American Type Culture Collection.

${ }^{c}$ DNA was labeled with [methyl $\left.{ }^{3} \mathrm{H}\right]$ thymine in vivo by using a thymine-requiring mutant.

${ }^{d}$ DNA was labeled with [methyl- $\left.{ }^{3} \mathrm{H}\right]$ deoxythymidine triphosphate in vitro by nick translation (6).

e NT, Not tested.

tured DNA that was prepared from a test strain and fixed on a filter (disk DNA) in $6 \times$ SSC $(1 \times$ SSC is $0.15 \mathrm{M} \mathrm{NaCl}$ plus $0.015 \mathrm{M}$ sodium citrate) containing $50 \%(\mathrm{vol} / \mathrm{vol})$ formamide at $37^{\circ} \mathrm{C}$ for $22.5 \mathrm{~h}$. The amount of the input DNA bound to the disk DNA was estimated by counting the radioactivity on the filter with a liquid scintillation counter (model LS-250; Beckman Instruments, Inc., Fullerton, Calif.).

Our results are shown in Table 1. Although data for several combinations of DNAs are lacking, including comparisons with the type strain of B. lentus (ATCC 10840), due to difficulties of DNA preparation, most of the $B$. firmus strains showed high homology with the DNA of the $B$. firmus type strain, ATCC 14575, and with the DNA of strain NRS 853; an exception was strain NRS 1560, whose DNA showed low homology (5\%) with the DNA of $B$. firmus ATCC
$14575^{\mathrm{T}}$. However, the strains labeled $B$. lentus showed low homology values, indicating that they may belong to a species independent from $B$. firmus. On the other hand, the DNA of one of the intermediate strains, NRS 1369 , showed high homology with the DNAs of 10 strains labeled $B$. firmus. Hence, strain NRS 1369 appears to belong to $B$. firmus rather than to $B$. lentus or the intermediate group. The hybridization data for the five strains designated $B$. lentus indicated that they should not be classified in a single species, as they showed low homology with each other, except for strains NRS 883 and NRS 1262 , which appeared to belong to the same species.

In conclusion, the strains classified as $B$. lentus should be separated from those classified as $B$. firmus, to which end the taxonomic criteria suggested by Gibson (1) are useful. However, 
the strains assigned to $B$. lentus are heterologous and cannot be classified into a single species. The same is true of most of the strains designated intermediate strains, as the homology values observed between them were generally low. Recently, Priest (5) described DNA homology data which support the homogeneity of four strains labeled $B$. firmus and separated $B$. lentus from $B$. firmus. However, the data of this author suggested that four strains labeled $B$. lentus (NCIB 8773, NRS 769, NRS 883, and a soil strain) and an intermediate strain (NRS 749) should be classified into a single species.

We are grateful to Ruth E. Gordon for providing strains used in this study and for her critical reading of the manuscript.

\section{LITERATURE CITED}

1. Gibson, T. 1935. The urea-decomposing microflora of the soils. I. Description and classification of the organisms. Zentralbl. Bakteriol. Parasitenkd. Infektionskr. Hyg. Abt. 2 92:364-380.

2. Gibson, T., and R. E. Gordon. 1974. Bacillus Cohn 1872, p.
529-550. In R. E. Buchanan and N. E. Gibbons (ed.), Bergey's manual of determinative bacteriology, 8 th $\mathrm{ed}$. The Williams \& Wilkins Co., Baltimore.

3. Gordon, R. E., J. L. Hyde, and J. A. Moore, Jr. 1977. Bacillus firmus-Bacillus lentus: a series or one species? Int. J. Syst. Bacteriol. 27:256-262.

4. Marmur, J. 1961. A procedure for the isolation of deoxyribonucleic acid from micro-organisms. J. Mol. Biol. 3:208218.

5. Priest, F. G. 1981. DNA homology in the genus Bacillus, p. 33-57. In R. C. W. Berkeley and M. Goodfellow (ed.), The aerobic endospore-forming bacteria: classification and identification. Academic Press, Inc., London.

6. Rigby, P. W. J., M. Dieckmann, C. Rhodes, and P. Berg. 1977. Labeling deoxyribonucleic acid to high specific activity in vitro by nick translation with DNA polymerase $I$. J. Mol. Biol. 113:237-251.

7. Seki, T., C.-K. Chung, H. Mikami, and Y. Oshima. 1978. Deoxyribonucleic acid homology and taxonomy of the genus Bacillus. Int. J. Syst. Bacteriol. 28:182-189.

8. Seki, T., T. Oshima, and Y. Oshima. 1975. Taxonomic study of Bacillus by deoxyribonucleic acid-deoxyribonucleic acid hybridization and interspecific transformation. Int. J. Syst. Bacteriol. 25:258-270.

9. Spizizen, J. 1958. Transformation of biochemically deficient strains of Bacillus subtilis by deoxyribonucleate. Proc. Natl. Acad. Sci. U.S.A. 44:1072-1078. 